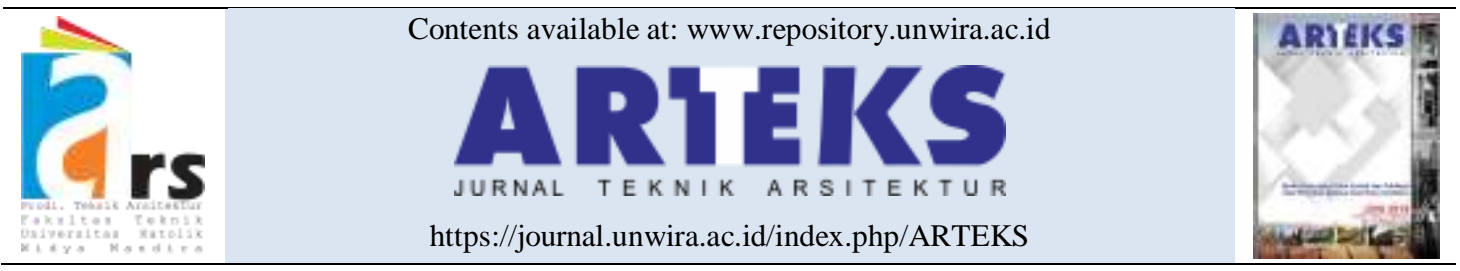

Research paper

doi: $10.30822 /$ arteks.v6i2.724

\title{
The impact of housing transformation to livability in North Bandung Peri-urban area
}

\author{
Romi B. Margono ${ }^{1}$, Yulia $^{2}$, Siswanti Zuraida ${ }^{3}$, Wiwik Dwi Pratiwi ${ }^{4 *}$ \\ ${ }^{1,4}$ Architecture, School of Policy, Planning and Development, Institut Teknologi Bandung \\ Jl. Ganesha 10, Bandung, Indonesia \\ ${ }^{2}$ IDN Liveable Cities, Delft, The Netherlands \\ ${ }^{3}$ Civil Engineering, Institut Teknologi Sains Bandung \\ Jl. Ganesha Boulevard, Bekasi, Indonesia
}

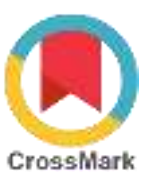

\begin{tabular}{|c|c|}
\hline ARTICLE INFO & ABSTRACT \\
\hline $\begin{array}{l}\text { Article history: } \\
\text { Received October } 31,2020 \\
\text { Received in revised form Dec. } 29,2020 \\
\text { Accepted January } 11,2021 \\
\text { Available online August } 01,2021\end{array}$ & $\begin{array}{l}\text { Urbanization has made Indonesian cities to grow spatially, causing } \\
\text { urban sprawl and transformation of rural areas into urban areas. In } \\
\text { between the urban and rural areas, there is peri-urban area that has } \\
\text { mixed characteristics of both. Areas with such characteristics can } \\
\text { be found easily in the outskirts of Bandung city. The growth of peri- }\end{array}$ \\
\hline $\begin{array}{l}\text { *Corresponding author: Wiwik Dwi } \\
\text { Pratiwi } \\
\text { Architecture, School of Policy, Planning and } \\
\text { Development, Institut Teknologi Bandung, } \\
\text { Indonesia } \\
\text { Email: wdratiwi@ar.itb.id } \\
\text { ORCID: https://orcid.org/0000-0003-0194- } \\
3783\end{array}$ & $\begin{array}{l}\text { urban areas in Bandung occurs simultaneously with the growing } \\
\text { tourism industries. This phenomenon caused a housing } \\
\text { transformation, which gives impacts to the livability of the area. This } \\
\text { article aims to analyze on how housing transformation in peri-urban } \\
\text { areas can affect the livability of the area by using the North Bandung } \\
\text { peri-urban area as a case study. The livability of peri-urban areas } \\
\text { seems overlooked since literatures often merely discuss on urban } \\
\text { areas. In fact, peri-urban areas occur due to urbanization and are } \\
\text { subject to change depends on urban areas growth. The result shows } \\
\text { that the housing transformation happened in peri-urban areas gives } \\
\text { positive impacts to social, economy, and spatial aspects, but } \\
\text { unfortunately not the environmental aspects. By the end of this } \\
\text { article, the Authors also give policy recommendations applied for } \\
\text { the area to maintain its livability. }\end{array}$ \\
\hline
\end{tabular}

\section{Introduction}

Indonesia, as a developing country, has grown faster than other Asian countries in term of urban population growth, which is $4,1 \%$ each year. By 2025 , it is projected that $68 \%$ of the country's population live in in (World Bank 2016). However, the notion of urbanization in Indonesia, which is traditionally understood as the migration of people who previously live in rural areas to urban area, has shifted. The population growth in urban areas is no longer driven by migration influx from rural to urban areas. For the recent decades, urbanization in Indonesia happened due to the spatial transformation of surrounding areas of cities which were previously showed rural characteristics into urban characteristics.

One of the Indonesian cities that is undergone massive urbanization is Bandung City, the capital of West Java Province. The spatial transformation of Bandung Metropolitan Area is rather sprawl and irregular to the North and South direction of Bandung and Cimahi City (Budiyantini and Pratiwi 2016). The transformation also happens in between the urban and rural area which is called peri-urban area that has unique mixed characteristics of both caused by tourism. Bandung is a favourite destination for people from surrounding cities and Jakarta. The city is famous for the urban tourism and natural attractions. 
The development of tourism activities pushed a tremendous spatial transformation: housings are transformed into commercial uses, such as restaurants, cafes, hotel, hostels, shops, and many more. This condition certainly gives impacts to the livability and quality of life in peri-urban areas. Reflecting on this, a question arises, "how are the impacts of housing transformation in periurban areas to the livability of the areas?"

This article aims to analyze further this topic by using North Bandung area as the case study. Firstly, this article will introduce fundamental concepts of livability and spatial transformation in peri-urban area - including both relations. Secondly, the case study is described. Thirdly, research method is explained, especially to measure the livability of the selected case study areas then followed with the analysis and field observation results. Lastly, this article is closed with the conclusion and recommendations.

Defining and measuring livability

The "livability" terminology is popular in urban development discourses. However, livability is interpreted differently based on the context, scale and point of views that are used in defining the terminology. In a simple way, livability refers to a condition of suitability for human living (Meriam-Webster 2020). However, this definition has many weaknesses: how do we measure that a certain condition is suitable? Suitable for which groups? It is almost impossible to achieve a definition that can be accepted globally since each inhabitant have various opinions regarding a suitable living environment.

Among many attempts to define livability, there are two prevalent notions. First notion highlights the minimum standard of living environment, that consists of physical and environmental aspects, to support the life of the residents (Ruth and Franklin 2014; The Economist Intelligence Unit 2019). Another notion focuses on the level of satisfaction of the residents upon their living environments; (Monocle 2019; Shita 2017).

So, how do we measure livability of a city or a certain area? There are a lot of livable cities indicators and indexes. Some of the well-known and widely-used indicators among others: Livable Community Guidelines by AARP Public Policy Institute (Kihl et al. 2005), Monocle Quality of Life Survey (Monocle 2019), Global Livability Index by the Economist Intelligence Unit (The Economist Intelligence Unit 2019) and Mercer
Quality of Life Survey Indicators (OkuliczKozaryn 2013).

By acknowledging the two prevalent notions in defining the livability concept and widely-used indicators, the author conceptualize livability as $a$ condition of a city or a certain area that can fulfil the minimum standard of living for its inhabitants that consists of economic aspects ("economically livable"), environmental aspects ("environmentally livable"), social aspects ("socially livable") and the combination of spatial-infrastructure-public service aspects ("spatially livable"). The indicators used in this article will be on table 1 in the research method section.

Peri-urban area: Emergence, triggers, and livability discourses

Peri-urban area or as peri-urban interface is a unique phenomenon, resulted by urbanization. The notion of peri-urban area firstly emerged in 1940s to give a special attention to a sudden population growth in the outskirt areas of cities in the United States and Western Europe. Suburban housings were grown followed by the development of road infrastructures outside the city and the change of characteristics of rural areas into urban areas, resulting areas which have mixed characteristics of both. At that time, the term "urban fringe" was used and adopted in academic literatures (Adell 1999). Nowadays, the exploration to define peri-urban area has grown from just focusing on spatial and physical transformation, but also focusing on social and economic characteristics (Laquinta and Drescher 2000). Nevertheless, spatial transformation remains dominant in academic literatures.

There are many triggers that caused the occurrence of peri-urban. Nevertheless, the underlined idea remains similar: a certain landuse that is perceived to have better economic prospects than the existing land-uses. For instance, large-scale industrial development in the outskirts of cities has led agricultural conversions into industries in Ho Chi Minh City, Vietnam (Kontgis et al. 2014). Meanwhile, in Indonesia the development of recreational and leisure facilities is the trigger for peri-urban occurrence (Budiyantini and Pratiwi 2016).

The topic of livability of peri-urban area is now emerging due to the fact that the growth of peri-urban areas has the most prominent current changes to urban structures. This topic is worth to explore since it seems overlooked and trends 
show that the significant growth of couple metropolitan areas, such as Jakarta (Indonesia) and Bangkok (Thailand), happen in peri-urban areas (Simon and Adam-Bradford 2016).

Case study overview

Bandung Peri-urban area

Peri-urban areas of Bandung occurs due to the uncontrolled sprawl development and the government's plan to developing certain areas outside Bandung City with a specific purpose. Thesecombination triggered the spatial transformation of the areas surrounding Bandung City into more urban characteristics supported by the development of infrastructures. In the context of Bandung Raya Metropolitan Area, peri-urban areas serve as the essential elements that support the urban area and the metropolitan area.

Peri-urban areas of Bandung Raya Metropolitan Area have various characteristics based on the degree of transformation. Some areas are more urbanized than the others. These areas usually located in adjacent areas of Bandung City and Cimahi City, as the core of the metropolitan area. Meanwhile, other areas have a mixed characteristic of urban and rural areas. The areas with this characteristic are mainly found in the south of Bandung City. There are also areas in the northern part of the metropolitan core that still have a strong rural characteristic even though the sign of urbanization appears (Budiyantini and Pratiwi 2016).
Housing transformation phenomenon in North Bandung Peri-urban area

The housing transformation in NorthBandung Peri-Urban Area is related with the government's plan to establish the Bandung Raya Metropolitan Area as the leading sector in urban tourism, creative industries and technology advancement in the West Java Province, as regulated by West Java Local Government Regulation No. 22/2010 regardingRegional Spatial Planning of West Java Province (Gubernur Jawa Barat 2010).

The most prevalent pattern is the transformation of housings into more commercial uses, such as hotels, cafes and restaurants. It shown economic force plays important role in the adaptation strategies (Prasetyo et al. 2020). Some of these transformations reuse the old housing buildings or require the destruction of the old housing buildings and build an entire new building or by adding new commercial uses within residential area.

Bandung peri-urban areas, especially North Bandung peri-urban areas, are very famous among local and foreign tourists. Bandung periurban areas have natural assets such as mountains, waterfalls, and lakes. Throughout the time, there are various recreational and leisure destinations as well as their supporting facilities that are built (see figure 1). 


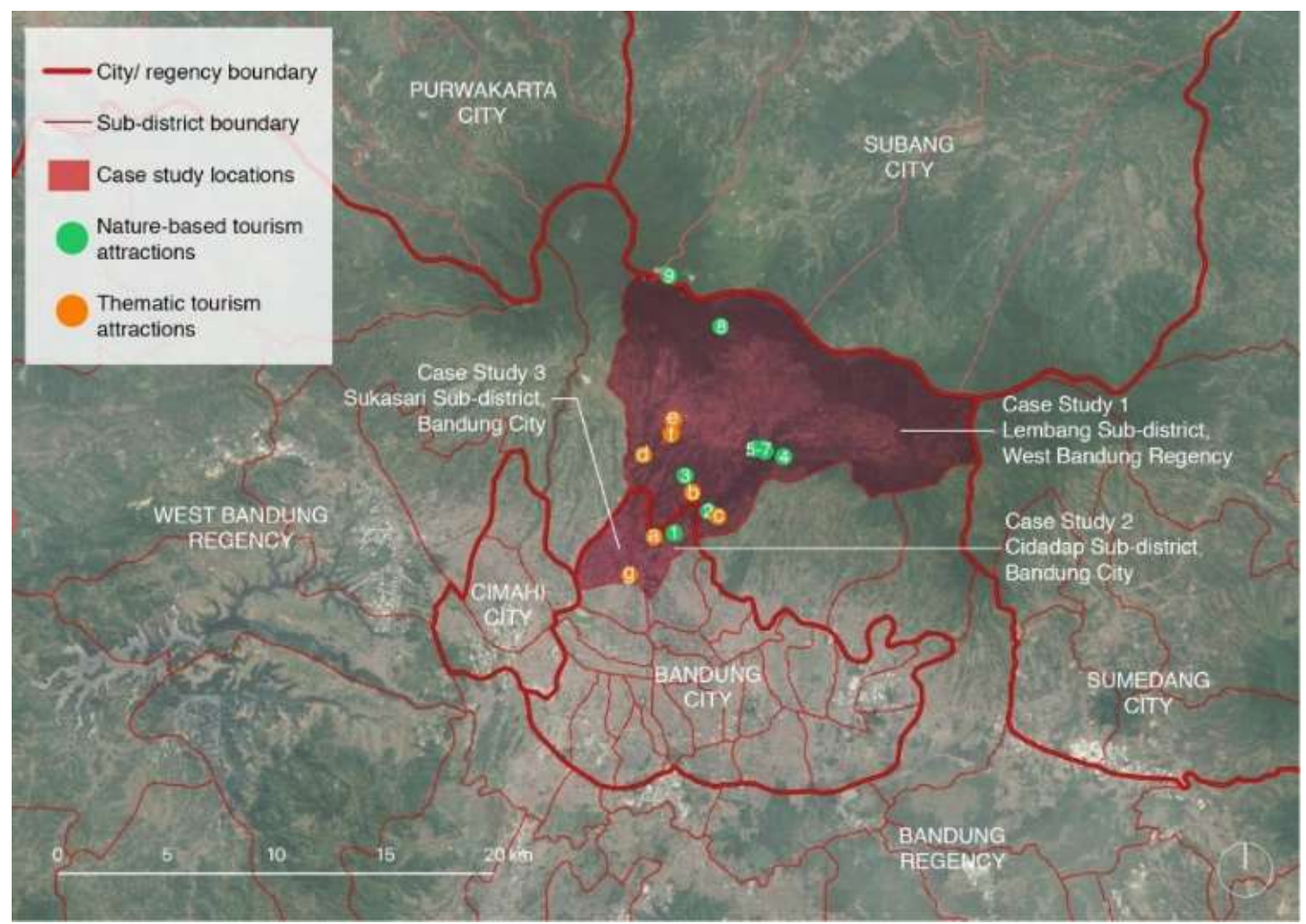

Figure 1. Case study locations

Furthermore, this article is written based on a study conducted in three sub-districts located on North Bandung peri-urban area, which are Sukasari, Cidadap and Lembang. These three locations selected because the presence of concentration of tourist attractions in the areas and these locations are the favorite among local and foreign tourists. Figure 1 shows the locations of these three case study areas within the Bandung Raya Metropolitan Area and the tourist attractions situated.

\section{Method}

The method that is used in the study combines quantitative and qualitative research method. The qualitative data gathered from 23 locations within three case study areas by direct observations and interviews with local residents. Spatial data and statistical data gathered as the quantitative data. All of these data are used to measure the livability of the selected case study locations based on the list of components and indicators derived from the literature study.

The list of components and indicators can be seen on table 1 . The study framework can be seen on figure 2.

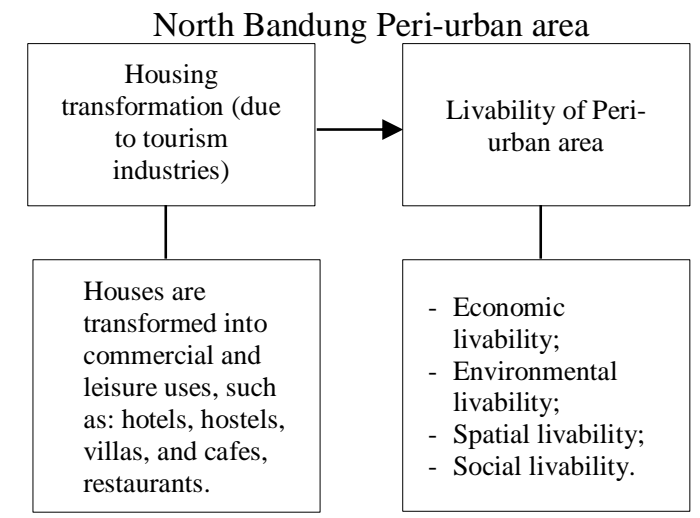

Figure 2. Research study framework 
Table 1. Livability components and indicators

\begin{tabular}{|c|c|c|c|}
\hline $\begin{array}{l}\text { Livability } \\
\text { components }\end{array}$ & Definitions & References & Indicators \\
\hline $\begin{array}{l}\text { Economically } \\
\text { livable } \\
(4 \text { points })\end{array}$ & $\begin{array}{l}\text { A condition where a } \\
\text { city or an area gives } \\
\text { job opportunities } \\
\text { and economic } \\
\text { improvement to the } \\
\text { residents. }\end{array}$ & $\begin{array}{l}\text { (Zanella, } \\
\text { Camanho, and } \\
\text { Dias 2015; Phillis, } \\
\text { Kouikoglou, and } \\
\text { Verdugo 2017; } \\
\text { Badan } \\
\text { Perencanaan } \\
\text { Pembangunan } \\
\text { Penelitian dan } \\
\text { Pengembangan } \\
\text { Kota Bandung } \\
\text { 2017). }\end{array}$ & $\begin{array}{l}\text { - Rate of employment for productive age population } \\
\text { group; } \\
\text { - Rate of unemployment for productive age population } \\
\text { group. }\end{array}$ \\
\hline $\begin{array}{l}\text { Socially livable } \\
\text { ( } 6 \text { points) }\end{array}$ & $\begin{array}{l}\text { A condition where a } \\
\text { city or an area gives } \\
\text { a feeling of safety, } \\
\text { security, tolerance } \\
\text { and sense of } \\
\text { community to all of } \\
\text { the residents. }\end{array}$ & $\begin{array}{l}\text { (The Economist } \\
\text { Intelligence Unit } \\
\text { 2019; Badan } \\
\text { Perencanaan } \\
\text { Pembangunan } \\
\text { Penelitian dan } \\
\text { Pengembangan } \\
\text { Kota Bandung } \\
\text { 2017). }\end{array}$ & $\begin{array}{l}\text { - The existence of community groups; } \\
\text { - The existence of community center; } \\
\text { - The existence of (regular) community activities. }\end{array}$ \\
\hline $\begin{array}{l}\text { Spatially livable } \\
\text { (28 points) }\end{array}$ & $\begin{array}{l}\text { A condition where a } \\
\text { city or an area gives } \\
\text { sufficient public } \\
\text { services, } \\
\text { infrastructure and } \\
\text { spatial arrangement } \\
\text { for the residents }\end{array}$ & $\begin{array}{l}\text { (Kihl et al. 2005; } \\
\text { Shita 2017; } \\
\text { Monocle 2019; } \\
\text { Sim 2019; } \\
\text { Sanders, } \\
\text { Zuidgeest, and } \\
\text { Geurs 2015). }\end{array}$ & $\begin{array}{l}\text { - The availability of emergency service: fire-extinguisher } \\
\text { stations } \\
\text { - The number of schools (elementary, junior high, and } \\
\text { high schools) } \\
\text { - The availability health services } \\
\text { - The availability of assistance and healthcare service for } \\
\text { people with disabilities, impairments and extraordinary } \\
\text { diseases (mental issue, alzheimers etc.) } \\
\text { - The number of outdoor excercise and leisure facilities. }\end{array}$ \\
\hline
\end{tabular}




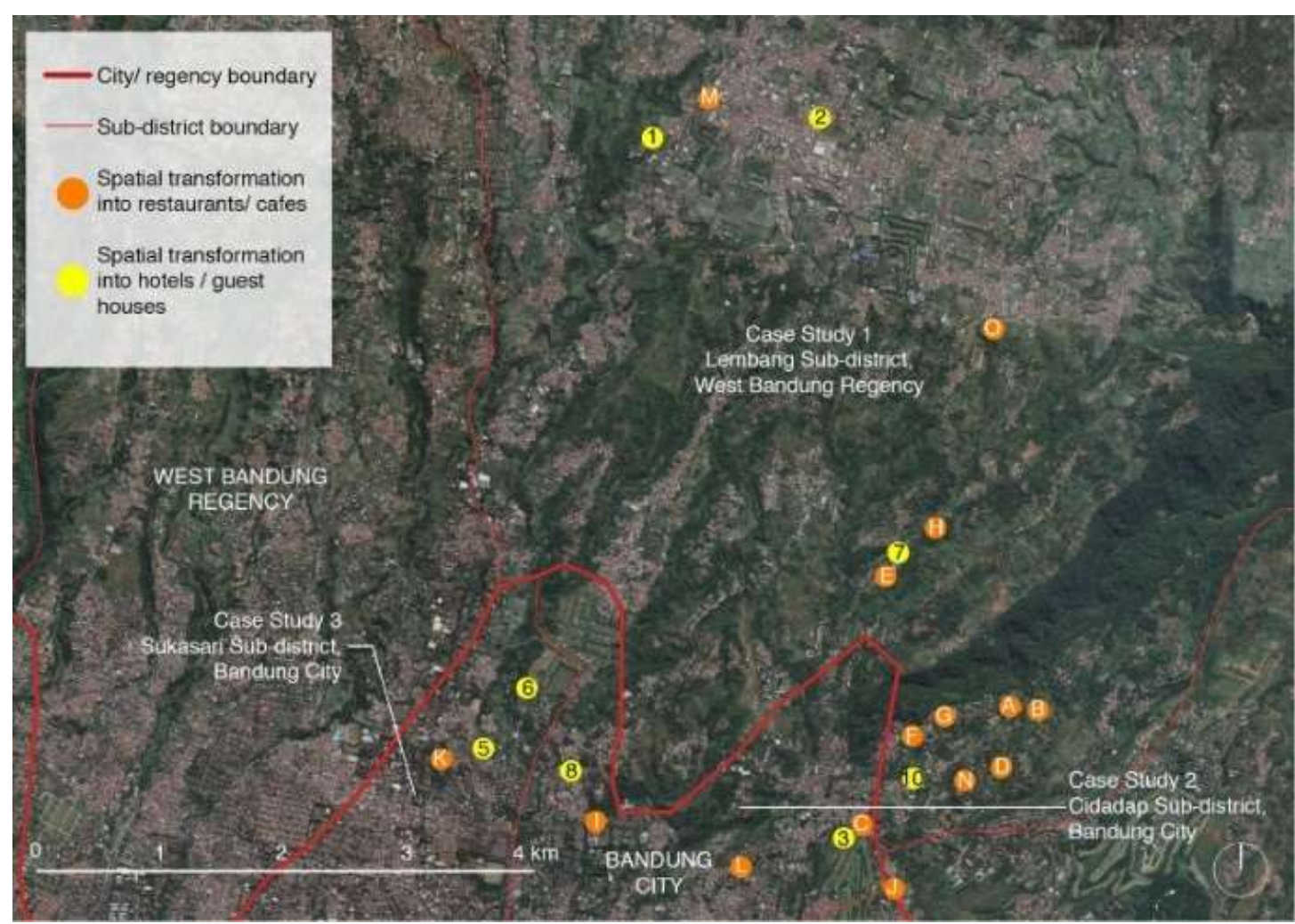

Figure 3. Spatial transformation observed location

\section{Result and discussion}

Spatial transformation

The surveys from the selected locations reveals that the tourism activity in surrounding neighborhood is the strong motive to change the houses into a new function. The emergence of various tourist destinations has increased the need for tourism facilities, especially for accommodation and restaurant or café. Those are the major functions that flourished and changing the existing neighborhood. The new functions are also creating a new job opportunity and increasing the land price.

In order to adapt with the new function, each of the houses need to be adjusted. Some spatial transformations occurred and creating a certain spatial quality from the perspective of the owner. It can be traced from the prior condition. The descriptive list of transformation can be seen on the following table 2 and figure 3 .

Table 2. Spatial transformation as seen in various observation locations

\begin{tabular}{|c|c|c|c|}
\hline Fuction & Subdistrict & Location & Transformation description \\
\hline \multirow[t]{11}{*}{ Restaurant/Café } & $\mathrm{L}$ & A & $\begin{array}{l}\text { Interior re-layout, bedroom into bakery display window, living room into } \\
\text { dining area, adding VIP room. }\end{array}$ \\
\hline & $\mathrm{L}$ & $\mathrm{B}$ & Adding island kitchen, façade alteration. \\
\hline & $\mathrm{C}$ & $\mathrm{C}$ & Additional building mass. \\
\hline & $\mathrm{L}$ & $\mathrm{D}$ & Façade alteration, adding restaurant kitchen, dining hall, praying room. \\
\hline & $\mathrm{L}$ & E & Adding outdoor dining room. \\
\hline & $\mathrm{L}$ & $\mathrm{F}$ & Interior re-layout, adding outdoor seating area, adding car parking area. \\
\hline & $\mathrm{L}$ & $\mathrm{G}$ & Creating outdoor seating, kitchen, and indoor seating. \\
\hline & $\mathrm{L}$ & $\mathrm{H}$ & $\begin{array}{l}\text { Creating outdoor seating, kitchen, mi bar, indoor seating, toilet, praying } \\
\text { room, parking area. }\end{array}$ \\
\hline & $\mathrm{C}$ & I & Interior re-layout, adding outdoor dining space. \\
\hline & $\mathrm{C}$ & $\mathrm{J}$ & $\begin{array}{l}\text { Creating semi outdoor space, basement, seating area, cashier spot, toilets, } \\
\text { praying room, outdoor dining space. }\end{array}$ \\
\hline & $\mathrm{S}$ & $\mathrm{K}$ & Removing fences, adding car parking area, façade and interior alteration. \\
\hline
\end{tabular}




\begin{tabular}{llll}
\hline & L & L & $\begin{array}{l}\text { Interior re-layout, adding seating, adding parking area, adding artworks } \\
\text { decoration. }\end{array}$ \\
\cline { 2 - 4 } & L & M & Interior re-layout, adding car parking area. \\
\cline { 2 - 4 } Accommodation & L & N & Façade and Interior alteration. \\
\cline { 2 - 4 } & L & 1 & Interior and façade alteration, adding villa unit. \\
\cline { 2 - 4 } & L & 2 & Interior re-layout, adding car parking area. \\
\cline { 2 - 4 } & C & 3 & Interior re-layout, coffee shop, adding gallery, workshop space. \\
\hline & S & 4 & Creating, house area, bedrooms, loft and balconies. \\
\hline & S & 5 & Interior re-layout. \\
\hline L & 6 & Façade alteration, adding fences. \\
\hline S & 7 & Creating outdoor pool, hotel rooms, car parking area. \\
\hline L & 8 & Façade alteration, adding common room, adding car parking area. \\
\hline
\end{tabular}

Note:

$\mathrm{L}=$ observed locations in Lembang sub-district;

$\mathrm{C}=$ observed locations in Cidadap sub-district;

$\mathrm{S}=$ observed locations in Sukasari sub-district.

From the table above, there are various spatial transformation. It is mainly by re-layout the interior and adding specific facilities for the new function. Furthermore, the alteration of façade is necessary for the house to signify the new function and to be easily visible for the upcoming visitors.

\section{Livability Assessment}

A livability assessment is conducted in the three case study areas by using a set of indicators mentioned on table 1, meanwhile the result of the assessment can be found on table 3. From table 3, it shown that the case studies are not achieved the maximum points (46 points). Furthermore, based on the total points achieved by each case study, Lembang has the highest point (38 points), followed by Cidadap (37 points) and Sukasari (34 points). It means that Lembang is the most livable area in this study.

Nevertheless, if each component in the livability assessment is also considered to draw a conclusion, each case study shows different result, rather conflicting to one another since each case study has different strength point in each component.

In the economic livability assessment, Cidadap, achieved the highest points for this component (4 points of maximum 4 points). Cidadap receives the highest point because the rate of employment per productive age population group is more than 50\% and the rate of unemployment per productive age population group is relatively small.

In term of environmentally livable component, Lembang, achieved the highest points (6 points of maximum 8 points). Lembang provided a healthy living environment. An interesting result show in socially livable component. It shown that all of case studies have the maximum points ( 6 points of maximum 6 points). It illustrates that the three sub-districts are able to give a feeling of safety, security, tolerance and sense of community to all of the residents which is presented by the existence of community groups (women group, youth group, and etc.), the existence of community center.

Furthermore, the last component would like to assess whether the area gives sufficient public services, infrastructure, and spatial arrangement for the residents. Based on this assessment, it shows that Lembang, receives the highest points (24 points of maximum 28 points). It means that Lembang is spatially livable compared to the other two case studies.

First lesson from livability assessment is that the livability situation of an area cannot be solely determined by looking at the final result of the entire assessment. As an area may have a weakness in a livability component but it has a strength in another livability component. Second lesson, it is almost impossible for an area to be livable in all components (economy, social, environment, and spatial). It is best if an area can determine own resources and assets and start using it to develop a more livable living environment. Each component of this assessment has different weight, expressed by different maximum points, it does not mean that one component is more important than the others.

Spatial transformation and its impacts to livability

Spatial transformations that found in the case studies indeed give impacts to the livability of the area in various aspects: provision of public 
services, environment, social, and economy, as also clearly seen in previous parts.

From economic perspective, it perceived giving opportunity for local people to get a job. The surrounding commercial function also gets benefits from the visitors or tourists. Following this fact, environmental livability has negative impact such as air and noise pollutions due to the increase number of private vehicle use. Meanwhile, the spatial livability has positive result in terms of area development and public service provisions.

Nevertheless, spatial transformation does not have a direct impact to social components of livability. It relies on social bonding among the residents. Our case study still has a strong bonding. It is proven with the existence of community activities and community centers. In several locations, the local business owners play an important role in the social development. Some of them even give their spaces to be used for community activities such as trainings or workshops.

\section{Conclusion}

In this study, livability of a peri-urban area is defined from four components: economy, environment, social, and spatial. First lesson is from the literature study, the livability situation of an area cannot be solely determined by looking at the final result of the entire assessment. It is because an area may have a weakness in a livability component but it has a strength in another livability component.

From the survey, the spatial transformation gives positive impacts to social, economy, and spatial aspects, but not the environmental aspects. Spatial transformation responding to new functions that support the tourism industry development in the area brings new job opportunities, further infrastructure developments and public transportation. Interestingly, the bond among the residents remains well-maintained. However, in term of environmental aspects, environmental issues and degradation occured. It shown the three case studies encounter air pollution issue due to the increase of motor vehicles.

Lastly, the authors would like to give recommendations for further research, it needs to explore the connection between spatial transformation and social bonds among the residents because peri-urban areas are subject to change, especially in term of the demography. Further research shall also concern to the secondary data limitation.

In terms of policy recommendation, the Authors suggest that the local government develops a regulation regarding eco-tourism as a basis for tourism development in the area. This regulation needs to be strongly promoted, wellenforced, and consider incentives for involved stakeholders.

Table 3. Result of livability assessment in three case studies

\begin{tabular}{|c|c|c|c|c|}
\hline \multirow{2}{*}{ Livability components } & \multirow{2}{*}{ Indicators } & \multicolumn{3}{|c|}{ Scores gained by each case study } \\
\hline & & Lembang & Cidadap & Sukasari \\
\hline \multirow{2}{*}{$\begin{array}{l}\text { Economically livable } \\
\text { (4 points) }\end{array}$} & $\begin{array}{l}\text { Rate of employment per productive age } \\
\text { population group }\end{array}$ & 1 & 2 & 1 \\
\hline & $\begin{array}{l}\text { Rate of unemployment per productive age } \\
\text { population group }\end{array}$ & 1 & 2 & 1 \\
\hline Subtotal & & 2 & 4 & 2 \\
\hline \multirow{4}{*}{$\begin{array}{l}\text { Environmentally livable } \\
\text { ( } 8 \text { points) }\end{array}$} & Air pollution level (Air Quality Index) & 1 & 1 & 1 \\
\hline & Water pollution level & 1 & 1 & 1 \\
\hline & Pleasant micro climate & 2 & 2 & 2 \\
\hline & The availability of waste recycles facilities & 2 & 0 & 0 \\
\hline Subtotal & & 6 & 4 & 4 \\
\hline \multirow{3}{*}{$\begin{array}{l}\text { Socially livable } \\
\text { (6 points) }\end{array}$} & The existence of community groups & 2 & 2 & 2 \\
\hline & The existence of community centre & 2 & 2 & 2 \\
\hline & $\begin{array}{l}\text { The existence of (regular) community } \\
\text { activities }\end{array}$ & 2 & 2 & 2 \\
\hline Subtotal & & 6 & 6 & 6 \\
\hline \multirow{5}{*}{$\begin{array}{l}\text { Spatially livable } \\
\text { (28 points) }\end{array}$} & The availability of sanitation & 1 & 1 & 2 \\
\hline & The coverage of clean water service & 2 & 2 & 1 \\
\hline & The coverage of electricity service & 2 & 2 & 2 \\
\hline & $\begin{array}{l}\text { The coverage of telecommunication } \\
\text { service (telephone and internet) }\end{array}$ & 2 & 2 & 2 \\
\hline & The availability of waste collection service & 2 & 2 & 2 \\
\hline
\end{tabular}




\begin{tabular}{|c|c|c|c|c|}
\hline \multirow{2}{*}{ Livability components } & \multirow{2}{*}{ Indicators } & \multicolumn{3}{|c|}{ Scores gained by each case study } \\
\hline & & Lembang & Cidadap & Sukasari \\
\hline & The availability of public transportation & 2 & 2 & 2 \\
\hline & Pedestrian friendly environment & 1 & 2 & 1 \\
\hline & Sufficient lighting & 1 & 2 & 2 \\
\hline & $\begin{array}{l}\text { The availability of emergency service: } \\
\text { police offices }\end{array}$ & 2 & 2 & 2 \\
\hline & $\begin{array}{l}\text { The availability of emergency service: } \\
\text { fire-extinguisher stations }\end{array}$ & 2 & 0 & 0 \\
\hline & $\begin{array}{l}\text { The number of schools (elementary, junior } \\
\text { high, and high schools) }\end{array}$ & 1 & 1 & 1 \\
\hline & $\begin{array}{l}\text { The availability of health services (health } \\
\text { community centre and hospitals) }\end{array}$ & 2 & 2 & 2 \\
\hline \multirow[t]{2}{*}{$\begin{array}{l}\text { Spatially livable } \\
\text { ( } 28 \text { points) }\end{array}$} & $\begin{array}{l}\text { The availability of assistance and } \\
\text { healthcare service for people with } \\
\text { disabilities, impairments and extraordinary } \\
\text { diseases (mental health, Alzheimer, etc) }\end{array}$ & 2 & 0 & 0 \\
\hline & $\begin{array}{l}\text { The number of outdoor exercise and } \\
\text { leisure facilities }\end{array}$ & 2 & 2 & 2 \\
\hline Subtotal & & 24 & 23 & 22 \\
\hline Total score & & 38 & 37 & 34 \\
\hline
\end{tabular}

\section{References}

Adell, German. 1999. Theories and Models of the Peri-Urban Interface: A Changing Conceptual Landscape. London: University College London. https://discovery.ucl.ac.uk/id/eprint/43/.

Badan Perencanaan Pembangunan Penelitian dan Pengembangan Kota Bandung. 2017. 'Laporan Akhir Penelitian Survey Index Liveable City'. Bandung.

Budiyantini, Yanti, and Vidya Pratiwi. 2016. 'Peri-Urban Typology of Bandung Metropolitan Area'. Procedia - Social and Behavioral Sciences 227 (July): 833-37. https://doi.org/10.1016/j.sbspro.2016.06.152.

Flynn, Andrew, Li Yu, Peter Feindt, and Chun Chen. 2016. 'Eco-Cities, Governance and Sustainable Lifestyles: The Case of the SinoSingapore Tianjin Eco-City'. Habitat International $53 \quad$ (78-86). https://doi.org/https://doi.org/10.1016/j.habita tint.2015.11.004.

Gubernur Jawa Barat. 2010. Peraturan Daerah Nomor 22 Tahun 2010 Tentang Rencana Tata Ruang Wilayah Provinsi Jawa Barat Tahun 2009-2029. Indonesia.

http://bappeda.jabarprov.go.id/wpcontent/uploads/2017/03/Perda-No-22Tahun-2010-Tentang-RTRWP-Jawa-Barat2009-2029.pdf.

Kihl, Mary, Dean Brennan, Neha Gabhawala, Jacqueline List, and Parul Mittal. 2005. Livable Communities: An Evaluation Guide.
Washington DC: AARP Public Policy Institute.

Kontgis, Caitlin, Annemarie Schneider, Jefferson Fox, Sumeet Saksena, James H. Spencer, and Miguel Castrence. 2014. 'Monitoring PeriUrbanization in the Greater Ho Chi Minh City Metropolitan Area'. Applied Geography 53 (September): $\quad 377-88$. https://doi.org/10.1016/j.apgeog.2014.06.029.

Laquinta, David L, and Axel W. Drescher. 2000. 'Defining the Peri-Urban: Rural-Urban Linkages and Institutional Connections'. Land Reform, Land Settlement and Cooperatives $2000 \quad$ (2): 8-26. https://www.cabdirect.org/cabdirect/abstract/ 20013046357.

Meriam-Webster. 2020. 'Meriam-Webster Dictionary'. Merriam-Webster.Com. 2020. https://www.merriamwebster.com/dictionary/liveability.

Monocle. 2019. 'The Monocle Quality of Life Survey'. Monocle. 2019.

Okulicz-Kozaryn, Adam. 2013. 'City Life: Rankings (Livability) Versus Perceptions (Satisfaction)'. Social Indicators Research $110 \quad$ (2): 433-51. https://doi.org/10.1007/s11205-011-9939-x.

Phillis, Yannis A., Vassilis S. Kouikoglou, and Catalina Verdugo. 2017. 'Urban Sustainability Assessment and Ranking of Cities'. Computers, Environment and Urban Systems 64 (July): 254-65. 
https://doi.org/10.1016/j.compenvurbsys.201 7.03.002.

Prasetyo, Eko Bagus, Andrew Cokro Putra, Bima Rahmaputra, and Agus Suharjono Ekomadyo. 2020. 'Architectural Adaptation Strategy of Shophouses in Jalan Tubagus Ismail, Bandung'. ARTEKS : Jurnal Teknik Arsitektur $5 \quad$ (1): $1-10$ https://doi.org/10.30822/arteks.v5i1.72.

Ruth, Matthias, and Rachel S. Franklin. 2014. 'Livability for All? Conceptual Limits and Practical Implications'. Applied Geography 49 (May): 18-23. https://doi.org/10.1016/j.apgeog.2013.09.018.

Sanders, Peter, Mark Zuidgeest, and Karst Geurs. 2015. 'Liveable Streets in Hanoi: A Principal Component Analysis'. Habitat International 49:

$547-58$.

https://doi.org/https://doi.org/10.1016/j.habita tint.2015.07.001.

Shita, Galuh. 2017. 'Indikator Kota Layak Huni'. Handal Selasar Group. 2017. https://www.handalselaras.com/seberapalayak-huni-kota-kota-di-indonesia/.

Sim, David. 2019. 'Nine Criteria for Liveable Urban Density'. In Soft City: Building Density for Everyday Life, edited by David Sim, 60464. Washington DC: Gehl Architects Finance \& Administration.

Simon, David, and Andrew Adam-Bradford. 2016. 'Archaeology and Contemporary Dynamics for More Sustainable, Resilient Cities in the Peri-Urban Interface'. In Balance Urban Development: Options and Strategies for Liveable Cities, edited by Basant Maheshwari, Vijay P. Singh, and Bhadranie Thoradeniya, 57-83. Sydney: Springer. https://doi.org/10.1007/978-3-319-281124_5.

The Economist Intelligence Unit. 2019. The Global Liveability Index 2019. London: The
Economist. https://www.eiu.com/n/theglobal-liveability-index-2019/.

Wang, Yong, Qian Ding, and Dafang Zhuang. 2015. 'An Eco-City Evaluation Method Based on Spatial Analysis Technology: A Case Study of Jiangsu Province, China'. Ecological Indicators $\quad 58$ : 37-46. https://doi.org/https://doi.org/10.1016/j.ecolin d.2015.05.032.

World Bank. 2016. 'Indonesia's Urban Story'. Worldbank.Org. 2016. https://www.worldbank.org/en/news/feature/ 2016/06/14/indonesia-urban-story.

$\mathrm{Yu}$, Li. 2014. 'Low Carbon Eco-City: New Approach for Chinese Urbanisation'. Habitat International 44: 102-10. https://doi.org/https://doi.org/10.1016/j.habita tint.2014.05.004.

Zanella, A., A. S. Camanho, and T. G. Dias. 2015. 'The Assessment of Cities' Livability Integrating Human Wellbeing and Environmental Impact'. Annals of Operations Research 226 (1): 695-726. https://doi.org/10.1007/s10479-014-1666-7.

\section{Author(s) contribution}

Romi Bramantyo Margono contributed to the research concepts preparation, methodologies, investigations, data analysis, visualization, articles drafting and revisions.

Yulia contribute to methodology, supervision, and validation.

Siswanti Zuraida contribute to methodology, supervision, and validation.

Wiwik Dwi Pratiwi contribute to the research concepts preparation and literature reviews, data analysis, of article drafts preparation and validation. 